\title{
Detection of The Existence of Viral Nervous Necrosis on Fry Cantang Grouper at Rain Season
}

\author{
Wahyu Nurlita, I Gde Suranaya Pandit *, Ni Made Darmadi \\ Fisheries Resource Management Study Program, Faculty of Agriculture, Warmadewa University, Indonesia \\ * Correspondent Author: Suranaya.pandit@yahoo.com
}

\begin{abstract}
Viral Nervous Necrosis (VNN) disease is one of the major causes of failure in grouper aquaculture activities. The pathogens attack the central nervous system, eyes retina, and reproductive organs. When the rainy season starts, it may generate lower water quality for aquaculture, which becomes a suitable condition for $V N N$ infections in fry cantang grouper. For this reason, there is an emerged need to do the detection of the existence of Viral Nervous Necrosis (VNN) pathogen fry cantang grouper cultured at the rain season. Data analysis was carried out in descriptive ways that aim to make data are presented by the actual situation without giving any treatment so that it can be easily discussed with existing theory to conclude. The examination on the presence of Viral Nervous Necrosis (VNN) disease on fry cantang grouper lived at rain season was conducted using two methods which are conventional PCR and Real-time PCR. From 20 samples of fry cantang grouper taken for this study, 5 samples were detected positive Viral Nervous Necrosis (VNN) its equal to the prevalence of 25\%. Histopathological observation on fry cantang grouper infected Viral Nervous Necrosis (VNN) show the appearance of vacuoles on ganglion cell layer, inner nuclear layer, and pigment epitel, a sign of lysis on the liver, vacuoles on the brain, necrosa, and hypertrophy on the brain, and the appearances of melano macrophage center on the kidney. The average water quality in the pond was reported at the temperature of $29.2^{\circ} \mathrm{C}$, salinity $33 \mathrm{ppt}$, and $\mathrm{pH} 8.3$.
\end{abstract}

Keywords: Fry cantang grouper, Viral Nervous Necrosis (VNN), Rain season)

\section{Introduction}

Cantang is a hybridization result between tiger grouper (Epinephelus fuscoguttatus) as a female and Kertang grouper (Epinephelus lanceolatus) as a male. The first research was conducted in $\mathrm{BPAB}$ Situbondo. Along with the development of grouper culture technology, groupers are cultivated in Indonesia, including in Bali, especially in the Gondol, Gerokgak district. Cantang grouper has an advantage where its growth is very fast compared to its parent. Right now, Bali exporting Cantang grouper to Vietnam, Malaysia, Singapore, Thailand, and Taiwan.

Viral Nervous Necrosis (VNN) is a serious problem that can cause the failure of grouper cultivated. It attacks the central nervous system, the retina of the eye, and reproductive organs. This disease can generally infect almost all phases of fish growth (larval and fry stages), and mortality can reach $100 \%$. Transmission of this disease can occur vertically or horizontally. In Indonesia, the first VNN attack occurred in snapper hatcheries in East Java in 1997. The next attack occurred in 1998 and caused 100\% death in duck grouper fish (Cromileptes altivelis) [1].

The condition of water quality due to the rainy season will affect water which enables the emergence of Viral Nervous Necrosis (VNN) in grouper hatchery. For this reason, it is necessary to detect the presence of Viral Nervous Necrosis (VNN) in the fried grouper that lives in the rainy season. This study aims to detect the presence of Viral Nervous Necrosis (VNN) in fry grouper that lives in the rainy season qualitatively, quantitatively, and its prevalence. The hypothesis of this study suggests that there is a Viral Nervous Necrosis (VNN) disease in grouper fry, both qualitatively, quantitatively, and its prevalence during the rainy season. 


\section{Material and Methods}

\subsection{Place and Time Research}

The research was starting with collecting the sample from Fish Breeder owned by Mr. Hendra Kurniawan in Penyabangan village, Gerokgak District, Buleleng regency, Bali. Molecular biology test and Histopathological test analysis conducted at the Fish Quarantine Laboratory in Denpasar. The time of the study was conducted from March 1 to May 31, 2019.

\subsection{Materials and tool}

The material used at the time of sampling is water maintenance media, oxygen. Necropsy of grouper fry with ice cubes and 95\% Ethanol fixation solution and NBF. RNA purification using RNA extraction, chloroform, isopropanol, ethanol 75\%, and DEPC $\mathrm{ddH}_{2} \mathrm{O}$. Qualitatively testing with conventional PCR using primarily with base arrangement for first PCR are ACACTGGAGTTTGAAATTCA and GTCTTGTTGAAGTTGTCCCA and nested PCR are CAACTGACAACGATCACACCTTC and CAATCGAACACTCCAGCGACA [2] one-step RTPCR, Go Taq Green, DNA marker 100bp, agarose, sbyrsave, and loading dye. Quantitative testing with real-time PCR uses primers with basic CAACTGACARCGAHCACAC and CCCACCAYTTGGCVAC bases and probes with TYTARGCRACTCGTGGTGCVG base arrangement [3], quantitecture RT-PCR kit. Histopathological testing using absolute ethanol, xylol, aqua dest, harris alum hematoxylin, acid alcohol, eosin, entelen, and paraffin.

The tools used are plastic bags, rubber bands, and coolboxes. Tools for necropsy are trays, rulers, scales, and dissecting sets. Tools for molecular biology testing are micropipette, microtip, $1.5 \mathrm{ml}$ microtube, $0.2 \mathrm{ml}$ microtube, refrigerated centrifuge, vortex, pastel, PCR work station, mini spin down, PCR and qPCR machines, analytical scales, hot plates, glassware, magnetic stirrer, horizontal gel electrophoresis system, software, and hardware. The tools for histopathological testing are tissue processor, tissue embedder, staining set cassette, embedding cassette, processing machine, stainless steel base mold, water bath, microtome, glass object, my coper's glass cover, and camera recorder.

\subsection{Data Analysis}

The data is presented in the form of pictures, curves, and tables then analyzed descriptively. the data can be presented following the actual situation without giving any treatment so that it can be easily discussed with existing theories to draw conclusions and suggestions. Prevalence is calculated using a formula.

Prevalence $=\frac{\text { Amount of groupers infected by VNN }}{\text { Total of sample groupers }} \times 100 \%$

\section{Results and Discussion}

\subsection{Morphological Identification of grouper fry}

Morphological observations of the body in the form of a compressed form and tend to be rounded, superior mouth type, rounded tail shape, and scales are steroid. Morphological identification of the grouper fry at 60 days can be seen in Figure 1. 


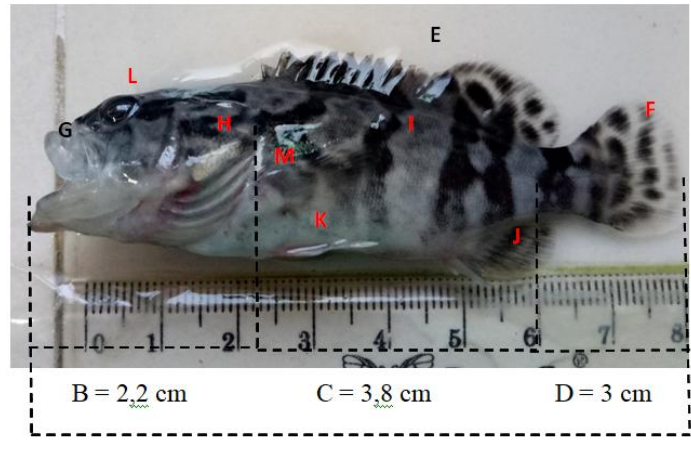

$\mathrm{A}=8 \mathrm{~cm}$

Figure1

Morphology of Grouper fry

Caption:

A: Total length

G: Mouth (Mouth)

B: Head length / Caput H: Operculum

C: Body length / Trunchus I: Sideline (Linea lateris)

D: Tail length / Caudal

$\mathrm{J}$ : Anal fin (Anal)

E: Dorsal Fins (Dorsal)

K: Abdominal Fins (Ventral)

F: Tail fin (Caudal)

L: Eyes

M: Pectoral Fins (Pectoral)

\subsection{Necropsy of Cantang fry}

The results showed clinical symptoms shown in Figure 2.
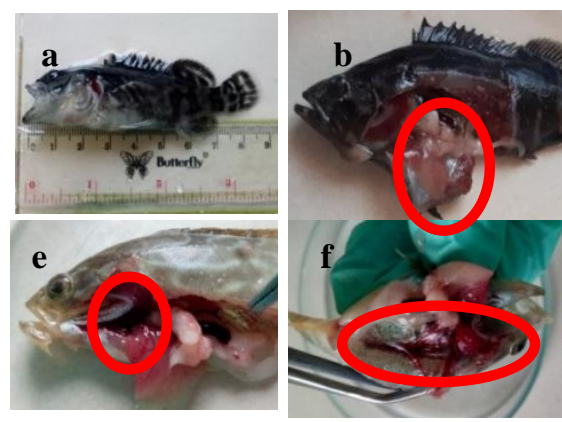

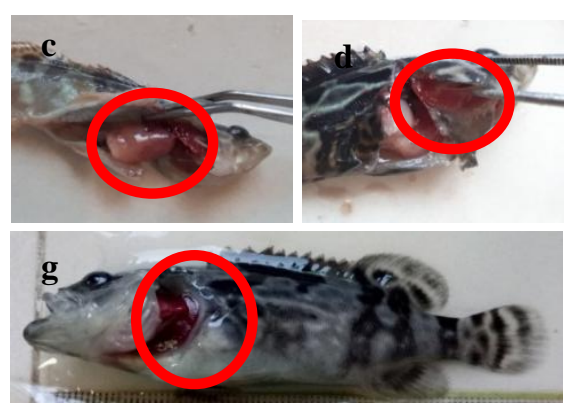

Figure 2

(a) dark body color, (b) pale liver, (c) swollen liver, some pale and partly haemoragii, (d) pale gills, (e) swollen spleen, (f) swollen kidneys and haemoragii; (g) open operculum and does not close the gills

perfectly.

This is following the opinion of [4] and [5] which states that the clinical symptoms in the physical fish and organs in the tiger grouper indicate that the fish have many injuries to the mouth and flaky fins, changes in swimming movements seem very clear with the wound at the bottom of the mouth, this condition indicates that the fish began to lose balance in swimming so that it is often seen crashing into the walls and bottom of the pond. The liver shows yellow, swollen spleen and swollen kidney

\subsection{Qualitative Method with Conventional PCR}

Conventional PCR Test Results to determine infection from 20 test samples of flak grouper with two replications show the following results (Figure 3). 

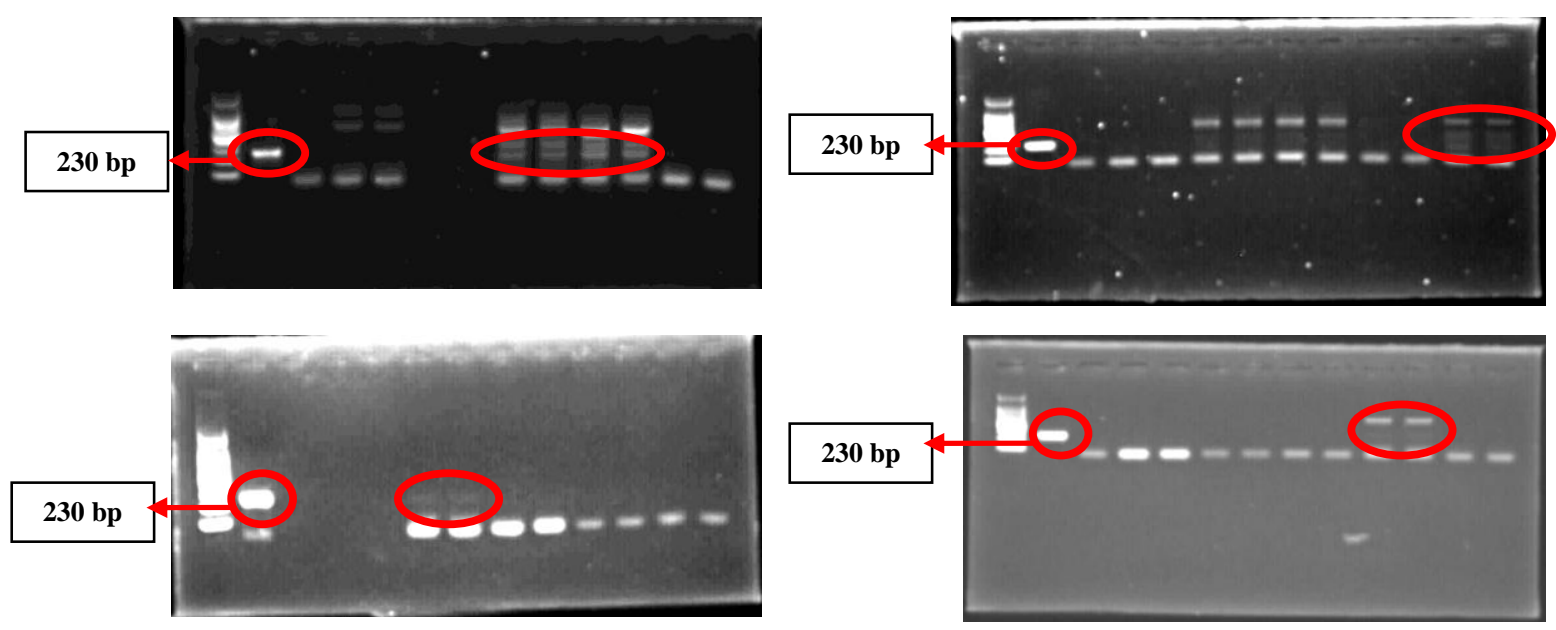

Figure 3

The results of testing qualitative methods with conventional PCR test samples 1 to 20

Based on the results of tests qualitative methods and Conventional PCR that out of 20 test samples of grouper plants that live in the rainy season are 5 that show positive results at $230 \mathrm{bp}$ and 15 show negative results (Figure 3). This is consistent with the opinion of [2] in [6] which states that in general PCR requires a short time, fast in reporting, high sensitivity and specificity and the primary design has been tested on the isolation of Betanodaviruses from the Mediterranean with Amplicon size is $605 \mathrm{bp}$ and $230 \mathrm{bp}$.

\subsection{Quantitative Method with Realtime PCR}

The results of the test using the realtime PCR method of 20 test samples of bleach grouper are shown in curve figure 4 and the interpretation of the results in Table 1.

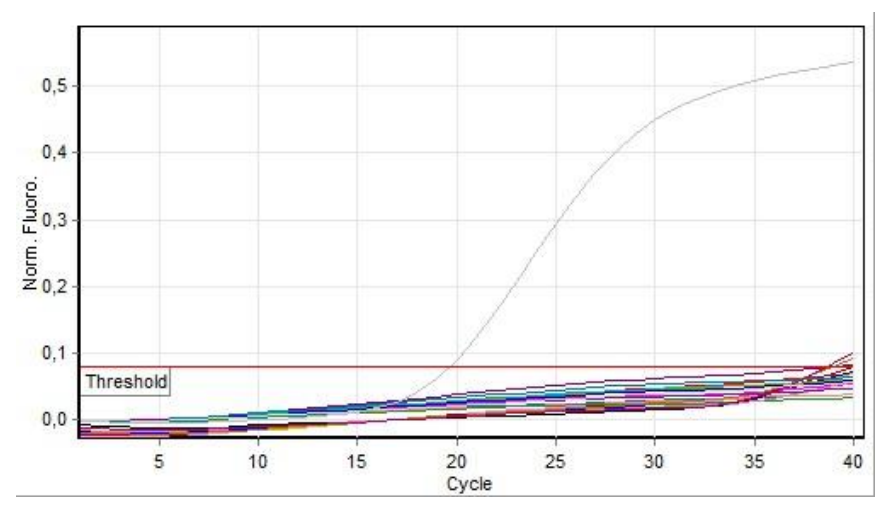

Figure 4

Quantitative data from cycling a.green test sample 1 to 2 
Table 1

Observation Results with Real-time PCR Method

\begin{tabular}{|c|c|c|c|c|c|c|}
\hline No. & color & $\begin{array}{l}\text { Test Sample } \\
\text { Code }\end{array}$ & Organ & $\mathrm{Ct}$ & Final Concentration & Test results \\
\hline 1 & & NTC & $\mathrm{ddH}_{2} \mathrm{O}$ & & & Negative \\
\hline 2 & & $\mathrm{~S} 1$ & Eyes, brain & & & Negative \\
\hline 3 & & $\mathrm{~S} 2$ & Eyes, brain & & & Negative \\
\hline 4 & & $\mathrm{~S} 3$ & Eyes, brain & 38.86 & 57 & Positive \\
\hline 5 & & $\mathrm{~S} 4$ & Eyes, brain & 39.92 & 41 & Positive \\
\hline 6 & & S5 & Eyes, brain & & & Negative \\
\hline 7 & & S6 & Eyes, brain & & & Negative \\
\hline 8 & & S7 & Eyes, brain & & & Negative \\
\hline 9 & & S8 & Eyes, brain & & & Negative \\
\hline 10 & & S9 & Eyes, brain & & & Negative \\
\hline 11 & & $\mathrm{~S} 10$ & Eyes, brain & 38.69 & 61 & Positive \\
\hline 19 & & S11 & Eyes, brain & & & Negative \\
\hline 20 & & S12 & Eyes, brain & & & Negative \\
\hline 21 & & S13 & Eyes, brain & 38.91 & 57 & Positive \\
\hline 22 & & S14 & Eyes, brain & & & Negative \\
\hline 23 & & S15 & Eyes, brain & & & Negative \\
\hline 24 & & S16 & Eyes, brain & & & Negative \\
\hline 25 & & S17 & Eyes, brain & & & Negative \\
\hline 26 & & S18 & Eyes, brain & & & Negative \\
\hline 27 & & S19 & Eyes, brain & 38.60 & 62 & Positive \\
\hline 28 & & S20 & Eyes, brain & & & Negative \\
\hline 29 & & $\begin{array}{l}\text { Control (+) } \\
\text { VNN } 10^{4}\end{array}$ & Standard & 19.67 & 24.750 & Positive \\
\hline
\end{tabular}

The analysis results are accurate because the NTC does not cut the threshold, the test sample is positive if the line forms a curve and intersects the threshold line, the test sample is negative if the line is linear and flat. Based on the results of the test with the realtime PCR method of 20 test samples of flak groupers that live in the rainy season are 5 positive and 15 negative with a virus concentration in the 3rd test sample with Ct 38.86 of 57 copies, the 4th test sample with Ct 39.92 as many as 41 copies, the 10th test sample with $\mathrm{Ct} 38.69$ were 61 copies, the 13th test sample with $\mathrm{Ct}$ 38.91 were 57 copies, and the 19th test sample with Ct 38.60 were 62 copies. This is by the opinion of [7] which states that the PCR realtime method is very appropriate in supporting the guarantee of successful cultivation because the method can detect and identify the presence of disease germs in fish bodies quantitatively, even up to under 10 copies per sample and very high sensitivity.

\subsection{Supporting Testing with Histopathology}

Histopathological observations of positive test samples for VNN are vacuoles in the ganglion cell layer (GCL), vacuoles in epithelial pigment, vacuoles in the inner nuclear layer (INL), vacuoles, necrosa and hypertrophy in the brain, melano macrophage center $(\mathrm{mmc})$ in the spleen and liver lysis can be seen in Figure 5. 

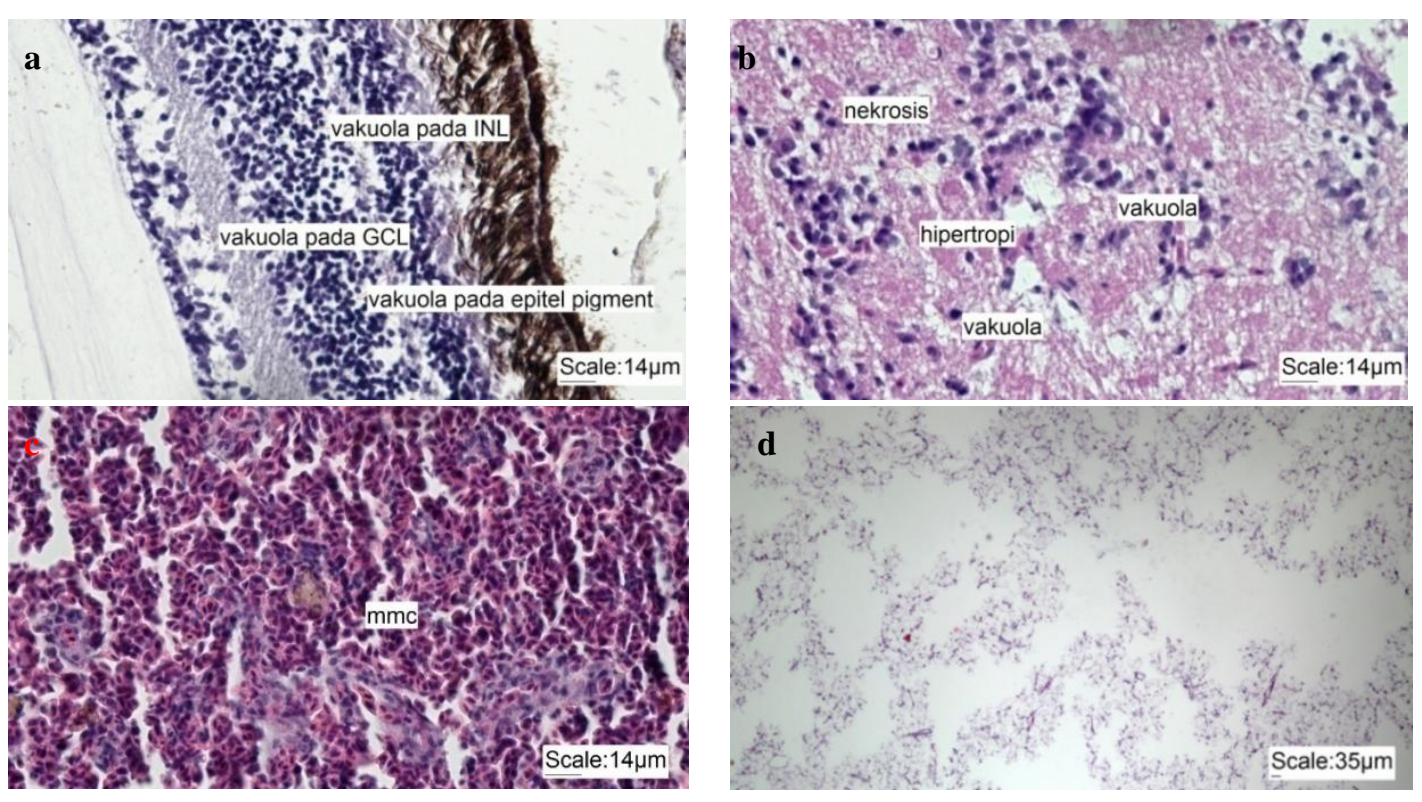

\section{Figure 5}

(a) vacuoles in the ganglion cell layer (GCL), vacuoles in the epithelial pigment, vacuoles in the inner nuclear layer (INL); (b vacuoles, necrosa and hypertrophy in the brain; (c) melano macrophages center $(\mathrm{mmc})$ in the spleen; (d) ) liver lysis

According to [8] which states that histopathological examination in groupers infected with Viral Nervous Necrosis (VNN) caused by a virus with observation using a light microscope on brain tissue shows necrosis and vacuolation $(\mathrm{Bar}=50 \mu \mathrm{m})$.

\subsection{Prevalence}

The results of the prevalence of test samples infected with VNN both qualitatively and quantitatively show $25 \%$ results. [9] that the value is included in the often category which illustrates that often infects the bleach grouper fry with a percentage of $25 \%$.

\subsection{Water quality}

The results of observing the quality of water maintenance media at the time of sampling can be seen in Table 2.

Table 2

Observation of water quality media maintenance

\begin{tabular}{lccc}
\hline Repeat & Temperature $\left({ }^{\circ} \mathrm{C}\right)$ & $\mathrm{pH}$ & Salinity $(\mathrm{ppt})$ \\
\hline I & 29.2 & 7.5 & 33 \\
II & 29.3 & 7.5 & 33 \\
III & 29.2 & 7.6 & 33 \\
Average & 29.2 & 7.5 & 33 \\
The range & $29-30$ & 8.3 & $15-33$ \\
explanation & Fulfill & Base & Fulfill \\
\hline
\end{tabular}

The results of water quality observations stated that the average temperature obtained was $29.2^{\circ} \mathrm{C}, 33 \mathrm{ppt}$ salinity and $\mathrm{pH} 8.3$, this figure shows that it is still in the optimal range to support the viability of the grouper fry. While this temperature range still allows the grouper bush fry to be infected with VNN according to the opinion of [10] which states that groupers infected with RGNNV (in-vitro optimum growth temperature: $25-30^{\circ} \mathrm{C}$ ) maintenance water temperature (16$28^{\circ} \mathrm{C}$ ) can affect the development of the disease. Higher mortality and the presence of earlier 
disease were observed at higher temperatures, while water temperatures higher than $31^{\circ} \mathrm{C}$ inhibited RGNNV proliferation in mouse grouper (Cromileptes altivelis). On the other hand, AHNV infection (BFNNV genotype, optimal: $15-20^{\circ} \mathrm{C}$ ) in the Atlantic halibut occurs at $6^{\circ} \mathrm{C}$.

\section{Conclusions}

Detection of Viral Nervous Necrosis (VNN) disease on the cantang grouper fry that lives during the rainy season qualitatively by conventional PCR methods and quantitatively by the Realtime PCR method 5 test samples show positive results at 230 base pairs (bp) with a virus concentration of 57 copies 41 copies, 61 copies, 57 copies and 62 copies. Histopathological testing shows vacuoles in the ganglion cell layer (GCL), vacuoles in the epithelial pigment, vacuoles in the inner nuclear layer (INL), vacuoles in the brain, necrosa and hypertrophy in the brain, melano macrophages (mmc) in the spleen, and liver lysis.

The prevalence of infected grouper fry that live in the rainy season against Viral Nervous Necrosis (VNN) which is tested both qualitatively with conventional PCR methods and quantitative with the Realtime PCR method shows results of $25 \%$ included in the often category which illustrates that VNN virus disease often infects the grouper fry.

\section{References}

[1] Afrianto E \& Liviawaty E. (2015). Penyakit Ikan. Jakarta:Penerbit Penebar Swadaya.

[2] Dalla V L, Zanella L, Patarnello P, Paolucci L, Belvedere P \& Colombo L. (2000). Development of a sensitive diagnostic assay for fish nervous necrosis virus based on RT - PCR plus nested PCR. J.Fish Dis., 23, 321-327.

[3] Panzarin V, Patarnello P, Mori A, Rampazzo E, Cappellozza E, Bovo G \& Cattoli G. (2010). Development and validation of a real-time TaqMan PCR assay for the detection of beta node virus in clinical specimens. Fish and Shellfish Pathology Departement. OIE Reference Laboratory for Viral Encephalopathy and Retinopathy. Viale dell' Universita. Italy. Arch Virol 155:1193-1203

[4] Grotmol S, Totland G K, Thorud K \& Hjeltnes B K. (1997). Vacuolating encephalopathy and retinopathy associated with a nodavirus-like agent: a probable cause of mass mortality of cultured larval and juvenile Atlantic halibut Hippoglossus hippoglossus. Diseases of Aquatic Organisms, 29(2), 85-97.

[5] Grotmol S, Bergh $\varnothing \&$ Totland G K. (1999). Transmission of viral encephalopathy and retinopathy (VER) to yolk-sac larvae of the Atlantic halibut Hippoglossus hippoglossus: occurrence of nodavirus in various organs and a possible route of infection. Diseases of Aquatic Organisms, 36(2), 95-106.

[6] OIE. (2018). Manual of diagnostic tests for aquatic animals, Chapter 2.3. 5.

[7] Maddocks (2017). Quantitative PCR: Things to Consider Chapter 4. Elsesevier Inc. http://dx.doi.org/10.1016/B978-0-12-802683-0.00004-6. Diakses 25 Maret 2019.

[8] Fukuda Y, Nguyen H D, Furuhashi M, \& Nakai T. (1996). Mass Mortality of Cultured Sevenband Grouper, Epinephelus septem fasciatus, Associated with Viral Nervous, Necrosis. Faculty of Applied Biological Science. Hiroshima University. Fish Pathology, 31(3), 165 - 170, 1996.9.

[9] Williams E H. \& Williams L B. (1996). Parasites of Offshore Big Gami Fishes of Puerto Rico and The Western Atlantic. Puerto Rico Department of Natural and Environmental Resources. San Juan, PR. The University of Puerto Rico. 383 pp

[10] Yuasa K, Koesharyani, Roza D, Mahardika K, Johnny F \& Zafran (2001). Manual For PCR Procedure: Rapid Diagnosis on Viral Nervous Necrosis (VNN) in Grouper. Lolitkanta - JICA Booklet No. 13. 35 pp. 